NISTIR 8223

\title{
Twenty-First Annual Report on Federal Agency Use of Voluntary Consensus Standards and Conformity Assessment Activities
}

\author{
Nathalie Rioux
}

This publication is available free of charge from:

https://doi.org/10.6028/NIST.IR.8223

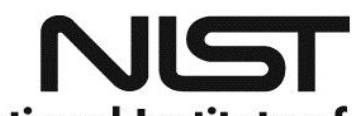

National Institute of Standards and Technology U.S. Department of Commerce 
NISTIR 8223

\title{
Twenty-First Annual Report on Federal Agency Use of Voluntary Consensus Standards and Conformity Assessment Activities
}

\author{
Nathalie Rioux \\ Standards Coordination Office \\ Standards Services
}

This publication is available free of charge from:

https://doi.org/10.6028/NIST.IR.8223

August 2018

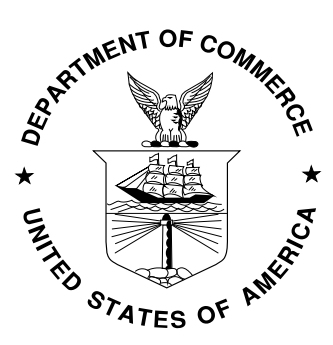

U.S. Department of Commerce

Wilbur L. Ross, Jr., Secretary

National Institute of Standards and Technology Walter Copan, NIST Director and Under Secretary of Commerce for Standards and Technology 


\section{Twenty-First Annual Report on Federal Agency Use of Voluntary Consensus Standards and Conformity Assessment Activities}

Each year the U.S. Department of Commerce (DOC) provides a report to the Office of Management and Budget (OMB) summarizing federal agency use of government unique standards (GUS) in lieu of voluntary consensus standards (VCS) during the previous fiscal year (FY), as required by Section 12(d)(3) of Public Law 104-113, the National Technology Transfer and Advancement Act of 1995 (NTTAA). By implementing the NTTAA and OMB Circular A119, Federal Participation in the Development and Use of Voluntary Consensus Standards and in Conformity Assessment Activities (Circular A-119), agencies seek to minimize their reliance on GUS by using VCS whenever possible to achieve the following goals:

- reduce costs and regulatory burden;

- provide incentives and opportunities encouraging long-term growth for U.S. enterprises;

- increase benefits from private sector expertise.

The FY 2017 summary, prepared by the National Institute of Standards and Technology (NIST), compiles the reports provided by 24 participating agencies listed in Appendix A. In these reports, agencies documented any new use of GUS in lieu of VCS during FY 2017 and provided a rationale for each new use. Agencies briefly described their activities undertaken to carry out provisions described in Circular A-119. Individual agency reports may be found at https://standards.gov/NTTAA/agency/index.cfm?fuseaction=agencyReports.main.

In early 2016, OMB updated Circular A-119 to incorporate the federal government's evolving strategy for standards development, promote agency participation in voluntary standards development, provide guidance on standards related to international trade obligations and conformity assessment, specify reporting requirements, and inform agencies of their statutory obligations related to establishing standards. The revised Circular A-119 simplified annual agency reporting requirements to more closely mirror the statutory requirements of the NTTAA resulting in more streamlined reporting by agencies.

For FY 2017, federal agencies reported four new GUS used in lieu of VCS as noted in Appendix $\mathrm{B}$, and one GUS rescinded (Appendix C). The Department of Labor introduced two GUS addressing worker safety that replaced multiple VCS. The Environmental Protection Agency (EPA) incorporated two GUS. The first more fully covers the requirements under 40 CFR part 63 subpart MM, "National Emission Standards for Hazardous Air Pollutants for Chemical Recovery Combustion Sources at Kraft, Soda, Sulfite, and Stand-Alone Semichemical Pulp Mills," compared to the existing VCS, while the second improves on an existing test method to provide consistency and clarification to laboratories testing for sprinkler efficiencies. The content of the second EPA GUS was submitted to the relevant standards development organization for consideration in a future revision of their VCS. The National Archives and Records 
Administration rescinded a GUS in lieu of VCS, replacing it with a newly revised VCS that addresses many of their initial concerns.

\section{Summary}

Since reporting began in 1997, 94 new GUS in lieu of VCS have been reported, and of this number, only 73 remain in lieu of private sector standards. The effectiveness of the NTTAA and Circular A-119 in encouraging an enhanced awareness and acceptance of private sector standards by federal agencies is demonstrated by the low numbers of reported new GUS used in lieu of VCS and the repeated review of opportunities to replace existing GUS with VCS. These activities suggest that federal agencies are increasingly likely to use standards developed by the private sector to meet their mission needs.

In accordance with its coordination role as defined in the NTTAA and Circular A-119, NIST continues to assist federal agencies and their stakeholders with standards and conformity assessment information, program support, guidance, and policy concerns. NIST hosts http://standards.gov, which offers ongoing practical guidance and information needed by agencies to implement the NTTAA successfully and report standards activities as required by the NTTAA and Circular A-119. This report fulfills the annual reporting requirements of both the NTTAA and Circular A-119. 


\author{
Access Board (ACCESS) \\ Consumer Product Safety Commission (CPSC) \\ Department of Agriculture (USDA) \\ Department of Commerce (DOC) \\ Department of Defense (DoD)* \\ Department of Education (ED) \\ Department of Energy (DOE) \\ Department of Health and Human Services (HHS) \\ Department of Homeland Security (DHS) \\ Department of Housing and Urban Development (HUD) \\ Department of the Interior (DOI) \\ Department of Justice (DOJ) \\ Department of Labor (DOL) \\ Department of State (DOS) \\ Department of Transportation (DOT) \\ Department of Treasury (TRES) \\ Environmental Protection Agency (EPA) \\ Federal Communications Commission (FCC) \\ Federal Trade Commission (FTC) \\ General Services Administration (GSA) \\ Government Publishing Office (GPO) \\ National Aeronautics and Space Administration (NASA)* \\ National Archives and Records Administration (NARA) \\ Nuclear Regulatory Commission (NRC)
}

* Agencies reporting on a categorical basis per OMB Circular A-119, Section 12. 


\section{Department of Labor:}

Government Standard: Personal Fall Protections Systems (29 CFR 1910.140)

[Incorporated: 2017]

Voluntary Standards: ANSI/ALI A14.3-2008, ANSI/ASSE A10.32-2012, ANSI/ASSE Z359.0-2012, ANSI/ASSE Z359.1-2007, ANSI/ASSE Z359.3-2007, ANSI/ASSE Z359.4-2013, ANSI/ASSE Z359.12-2009, ANSI/IWCA I-14.1-2001

Rationale: The Agency believes that it is less burdensome for the regulated community to use the one OSHA standard rather than require the use of numerous (8) individual consensus standards.

Government Standard: Walking-Working Surfaces (29 CFR 1910 Subpart D) [Incorporated: 2017]

Voluntary Standards: ANSI/ASSE Z359.0-2012, ANSI A14.1-2007, ANSI A14.22007, ANSI A14.3-2008, ANSI A14.5-2007, ANSI A14.7-2011, ANSI/TIA 222-G1996, ANSI/TIA 222-G-2005, ASTM C 478-13, ASTM A 394-08, ANSI/ASSE A1264.1-2007, NFPA 101-2012, ICC IBC-2012, ANSI/ITSDF B56.1-2012, ASME/ANSI MH14.1-1987, ANSI MH30.1-2007, ANSI MH30.2-2005, ANSI/ASSE Z359.4-2012, ANSI/IWCA I-14.1-2001, ANSI/ASSE A10.18-2012

Rationale: The Agency believes that it is less burdensome for the regulated community to use the one OSHA standard rather than require the use of numerous (20) individual consensus standards.

\section{Environment Protection Agency:}

Government Standard: EPA Method 29, "Metals Emissions from Stationary Sources" [Incorporated: 2017]

Voluntary Standard: ASTM D6784-02 (Reapproved 2008), "Standard Test Method for Elemental, Oxidized, Particle-Bound and Total Mercury Gas Generated from Coal-Fired Stationary Sources (Ontario Hydro Method)",

Rationale: The use of this voluntary consensus standard would be impractical because this standard is only acceptable as an alternative to the portion of EPA Method 29 for mercury, and emissions testing for mercury alone is not required under 40 CFR part 63, subpart MM. 
Government Standard: WaterSense Specification for Spray Sprinkler Bodies Appendix B: Spray Sprinkler Body Performance Test Method

[Incorporated: 2017]

Voluntary Standard: ASABE/ICC 802-2014, "Landscape Irrigation Sprinkler and Emitter Standard"

Rationale: WaterSense used ASABE/ICC 802-2014 (section 303.5.2) as the basis for its sprinkler performance test. However, no product testing was done by the ASABE/ICC standard development committee prior to publishing the standard. When WaterSense did this testing many changes had to be made to eliminate redundant steps, correct deficiencies in the method, and provide sufficient detail to run the test consistently at any laboratory. WaterSense has submitted the revised method to the ASABE/ICC 802 committee for consideration in the revision of the standard. 


\section{National Archives and Records Administration (NARA)}

Government Standard: Lifecycle Data Requirements Guide, Second Edition (January 18, 2002) (NARA standard) [Incorporated: 2016]

[Rescinded: 2017]

Voluntary Standard: RDA Steering Committee: Resource Description and Access 2015 Revision

Rationale: NARA introduced their standard because the voluntary standard of the Resource Description and Access (RDA) did not meet the precise needs of the agency at that time. In FY2017, NARA began using the recently revised RDA standard and rescinded their own. 